\author{
Cu-6 wt\% Ni-1.4 wt\% Si 합금의 압연 후 기계적 성질에 미치는 \\ 시효전 처리 영향 \\ 이상진 ${ }^{1,2} \cdot$ 신현석 ${ }^{1,3} \cdot$ 최은애 ${ }^{1} \cdot$ 안지혁 ${ }^{1} \cdot$ 최윤석 ${ }^{2, *} \cdot$ 김상식 ${ }^{3} \cdot$ 이재현 ${ }^{4} \cdot$ 한승전 ${ }^{1, *}$ \\ 1 한국기계연구원 부설 재료연구소 재료공정혁신연구본부 \\ ${ }^{2}$ 부산대학교 재료공학과 \\ 3 경상대학교 나노신소재융합공학과 \\ 4창원대학교 신금속재료공학과
}

\title{
Effect of Pre-Aging Treatment on the Mechanical Properties of Cold Rolled Cu-6 wt\% Ni-1.4 wt\% Si Alloy
}

\author{
Sang Jin Lee ${ }^{1,2}$, Hyeon Seok Shin ${ }^{1,3}$, Eun-Ae Choi ${ }^{1}$, Jee Hyuk Ahn', Yoonsuk Choi ${ }^{2, *}$, \\ Sangshik Kim ${ }^{3}$, Jehyun $\mathrm{Lee}^{4}$, and Seung Zeon Han ${ }^{1, *}$ \\ ${ }^{1}$ Materials Processing Innovation Research Division, Korea Institute of Materials Science, Changwon 51508, Republic of Korea \\ ${ }^{2}$ School of Materials Science and Engineering, Pusan National University, Busan 46241, Republic of Korea \\ ${ }^{3}$ Dept. of Materials Engineering and Convergence Technology, ReCAPT Gyeongsang National University, Jinju 52828, \\ Republic of Korea \\ ${ }^{4}$ Department of Materials Science and Engineering, Changwon National University, Changwon 51140, Republic of Korea
}

\begin{abstract}
Cu}-\mathrm{Ni}-\mathrm{Si}$ alloys were strengthened by $\mathrm{Ni}_{2} \mathrm{Si}$ intermetallic compound precipitation in a $\mathrm{Cu}$ matrix during aging. The $\mathrm{Cu}-6 \mathrm{wt} \% \mathrm{Ni}-1.4 \mathrm{wt} \% \mathrm{Si}$ alloy was prepared by water quenching (solution treatment) or air cooling (homogenization treatment) after heating $980^{\circ} \mathrm{C}$ for 2 hours and aging at $500{ }^{\circ} \mathrm{C}$ for 6 hours. After maintaining a high temperature single phase region, the structure of the precipitate in the matrix was changed significantly by varying the cooling rate. The solution treated aged alloy had discontinuous precipitation with fiber shaped precipitates throughout the specimen, however, the alloy with homogenization had normal spherical shaped particles. The aged alloy after homogenization treatment had higher strength, ductility and electrical conductivity, of $628 \mathrm{MPa}, 18 \%, 48 \%$ IACS, respectively, than aged alloy after solution treatment, which had $582 \mathrm{MPa}, 15.5 \%$ and $50 \%$ IACS, respectively. In contrast to the tendency of values after aging, after rolling and a $75 \%$ area reduction at room temperature after homogenization treatment the alloy had lower strength, ductility and electrical conductivity, of $774 \mathrm{MPa}, 10.5 \%, 48 \%$ IACS, than the alloy after solution treatment, with $885 \mathrm{MPa}, 6.5 \%$, and $48 \%$ IACS, respectively. The Cu- $6 \mathrm{wt} \% \mathrm{Ni}-1.4 \mathrm{wt} \% \mathrm{Si}$ alloy with fully discontinuous precipitation had lower strength and higher electrical conductivity than the counterpart alloy with normal precipitation. However, inversely, the strength increased compared to the alloy with normal precipitation after rolling with $75 \%$ area reduction, without sacrificing electrical conductivity.
\end{abstract}

(Received April 23, 2020; Accepted May 25, 2020)

Keywords: Cu-Ni-Si alloy, aging, $\mathrm{Ni}_{2} \mathrm{Si}$ intermetallic compound, precipitation hardening, electrical conductivity, normal precipitation, discontinuous precipitation.

- 이상진·신현석: 석사과정, 최은애·안지혁·한승전: 연구원, 최윤석·김상식·이재 현: 교수

*Corresponding Author: Seung Zeon Han

[Tel: +82-55-280-3331, E-mail: szhan@kims.re.kr]

*Corresponding Author: Yoonsuk Choi

[Tel: +82-51-510-2382, E-mail: choiys@pusan.ac.kr]

Copyright (C) The Korean Institute of Metals and Materials

\section{1. 서 론}

구리 합금은 다른 합금과는 달리 색상을 가지고 있는 금 속 중의 하나이다. 색상을 가지고 있는 금, 은 그리고 구 리 중 가장 저가이기 때문에 장식용으로 사용되기도 한다 [1,2]. 또한 다른 합금에 비해 높은 전기전도도를 가지기 
때문에, 적정한 강도가 확보될 경우, 전기 및 전자 부품의 핵심소재로 사용될 수 있다. 전기, 전자 그리고 정보통신 부품 소재는 외력에 변형되지 않는 충분한 강도와 효과적 인 전력 또는 신호전달을 위해 우수한 전기전도도가 필요 하다. 구리 합금은 전기전도도가 은 다음으로 우수하기 때 문에, 강도와 전기전도도, 두가지 핵심 특성을 가진 합금을 경제적으로 제조할 수 있다. 그런데, 전기전도도는 강도가 증가할수록 감소하는 상반특성이다. 합금화 그리고 가공열 처리 공정을 이용하여 강도를 향상시킬 경우, 구리 합금의 전기전도도는 필연적으로 감소하는 특성을 가진다 [3-13]. 구리 합금이 실제로 산업계에 응용되기 위해서는 제조시 적절한 경제성을 가짐과 동시에 우수한 강도와 전기전도도 를 가져야 한다. 구리합금의 여러 강화기구 중 석출경화는 비교적 높은 전기전도도와 강도를 동시에 구현할 수 있어 산업계에 널리 사용되고 있다 [6-19]. 일반적으로 석출강화 형 동합금은 $\mathrm{Cu}-\mathrm{Ni}-\mathrm{Si}$ [7-10], $\mathrm{Cu}-\mathrm{Ti}$ [13-17], $\mathrm{Cu}-\mathrm{Fe}$ $[18,19]$ 그리고 $\mathrm{Cu}-\mathrm{Be}[21,22]$ 합금이 있으며, 그 중에서 도 $\mathrm{Cu}-\mathrm{Ni}-\mathrm{Si}$ 합금은 다른 합금에 비해 높은 강도와 전기 전도도를 가지기 때문에 커넥터 소재로써 각광을 받고 있 다. [7-10]. 과포화 고용된 $\mathrm{Cu}-\mathrm{Ni}-\mathrm{Si}$ 합금을 시효 시, 구형 의 $\mathrm{d}-\mathrm{Ni}_{2} \mathrm{Si}$ (orthorhombic structure) 이 생성되고, 시효를 계속할 경우, 입계에서 $\mathrm{d}-\mathrm{Ni}_{2} \mathrm{Si}$ 이 라멜라 (섬유) 형태로 성 장한다. 전자를 연속 석출(continuous precipitation), 그리 고 후자를 불연속 석출(discontinuous precipitation)이라고 한다. 불연속 석출의 발생은 강도의 급격한 저하를 초래한 다 [6-8]. 불연속 석출물을 의도적으로 시편 전역에 형성시 켜 나노 크기의 섬유 복합재료를 제조하고 강도를 향상시 킨 연구가 활발히 진행되고 있다 $[7,8,23]$. 그런데, 합금 전체에 불연속 석출물을 생성시키기 위해선 과시효가 요구 되기 때문에 추가적인 에너지 소모가 일어난다. 그래서, 구 형인 연속 석출물 (Continuous precipitation; $\mathrm{CP}$ )이 불연 속 석출물 (Discontinuous precipitation; DP) 보다 석출강 화합금에 더 선호되는 편이다.

이 전의 연구에서 [8], $\mathrm{Cu}-\mathrm{Ni}-\mathrm{Si}$ 합금을 균질화 (homogenization) 및 용체화 (solution) 처리를 비교한 결 과, 균질화 처리된 합금에서 불연속 석출물 형성이 억제되 었고, 따라서, 균질화 처리 후 시효한 합금이 용체화 처리 한 시편 보다 높은 강도를 가지는 것을 나타냈다. 그런데, 실제 동합금은 판재 형태의 원소재가 주로 요구되기 때문 에, 냉간 압연을 이용하여 최종제품을 제조하는 것이 일반 적이다. 따라서, 본 연구에서는 시효 전 처리에 의해 일반 석출 및 불연속 석출된 합금의 $75 \%$ 단면적 감소율로 상 온 압연 가공 후, 미세조직 변화에 따른 기계적 및 전기적
특성을 고찰하였다. 그 결과, 용체화처리 후 시효한 합금은 압연 후, 인장강도 $885 \mathrm{MPa}$, 전기전도도 $48.5 \%$ IACS (International Annealed Copper Standard; 순동 = $100 \%$, 그리고 균질화 처리 후 시효한 합금은 $782 \mathrm{MPa}$ 과 $48 \%$ 의 인장강도와 전기전도도를 각각 나타내었다.

\section{2. 실험방법}

본 연구에서 순도 $99.99 \% \mathrm{Cu}$ 와 $\mathrm{Si}$ 그리고 순도 99.95\% Ni을 사용하여 $\mathrm{Ar}$ 가스 분위기에서 진공 유도 용 해 (vacuum induction melting, VIM) 하였고, 두께 $25 \mathrm{~mm}$, 폭 $125 \mathrm{~mm}$ 그리고 길이 $400 \mathrm{~mm}$ 의 Cu-6wt\%Ni$1.4 \mathrm{wi} \% \mathrm{Si}$ 합금을 제조하였다. 주조된 잉곳은 $950{ }^{\circ} \mathrm{C}$ 에서 2 시간 유지한 후 두께 $5 \mathrm{~mm}$ (단면적 감소율 $80 \%$ )로 열간 압연하였다. 그 후 $980{ }^{\circ} \mathrm{C}$ 의 아르곤 가스 분위기에서 열처 리 한 후, 수냉 (용체화) 또는 공냉 (균질화)을 하였다. 수 냉 및 공냉 시편의 표면 냉각 속도는 각각 $380{ }^{\circ} \mathrm{C} / \mathrm{sec}$ 와 $13{ }^{\circ} \mathrm{C} / \mathrm{sec}$ 였다. 용체화 또는 균질화 처리된 시편을 450 및 $500{ }^{\circ} \mathrm{C}$ 에서 시효하였고, 시효 후에 미치는 가공 (working)의 효과를 고찰하기 위해, $75 \%$ 단면적 감소율로 냉간 압연하였다. 열간 압연, 용체화 및 균질화 처리, 시효 그리고 압연된 각각의 합금을 판상 시험편 (ASTM E8M) 으로 가공한 후 상온에서 인장시험 하였다. 일련의 실험과 정은 그림 1 에 나타내었다. 각 시편을 에폭시 수지로 콜드 마운팅 (cold mounting)한 후 $\mathrm{SiC}$ 연마지와 콜로이달 실 리카 현탄액 (colloidal silica suspension)을 이용하여 기계 연마 하였다. 연마한 시편을 에칭액 $\left(\mathrm{FeCl}_{3} 6 \mathrm{H}_{2} \mathrm{O}: \mathrm{HCl}\right.$ : $\mathrm{H}_{2} \mathrm{O}=5 \mathrm{~g}: 12.5 \mathrm{ml}: 100 \mathrm{ml}$ )에서 3 초간 에칭한 후 광학 현미경 (optical microscope, OM, OLYMPUS, GX51)과 전계 방사형 주사전자현미경 (field emission scanning electron microscope, FE-SEM, JEOL, JSM-7001F)을 이 용하여 미세조직을 관찰하였다. 각 시편의 석출물을 $200-\mathrm{kV}$ 전계 방사형 투과전자현미경 (field emission transmission electron microscope, FE-TEM, JEOL, JEOL-2100F)을 이용하여 분석하였다. TEM 시편은 기계연마 후 $250 \mathrm{ml}$ 인산, $500 \mathrm{ml}$ 증류수, $50 \mathrm{ml}$ 프로판올, $5 \mathrm{~g}$ 우레아 (D2) 용액으로 제트폴리싱 (jet polishing)하여 제작하였다. 인장 특성은 인장 시험기 (tensile tester, Instron, 5982)와 25 $\mathrm{mm}$ 신율계 (extensometer)를 사용하여 $2 \mathrm{~mm} / \mathrm{min}$ 의 속도로 시험하였다. 그리고 미소경도계 (micro-Vickers hardness, Matsuzawa, MX70)를 이용하여 하중 $0.2 \mathrm{kgf}$ 으로 경도를 측정하였다. 전기전도도는 $30 \mathrm{~cm}$ 이상의 시편을 준비 후 YOKOGAWA 장비를 이용하여 double bridge 방법 [20] 


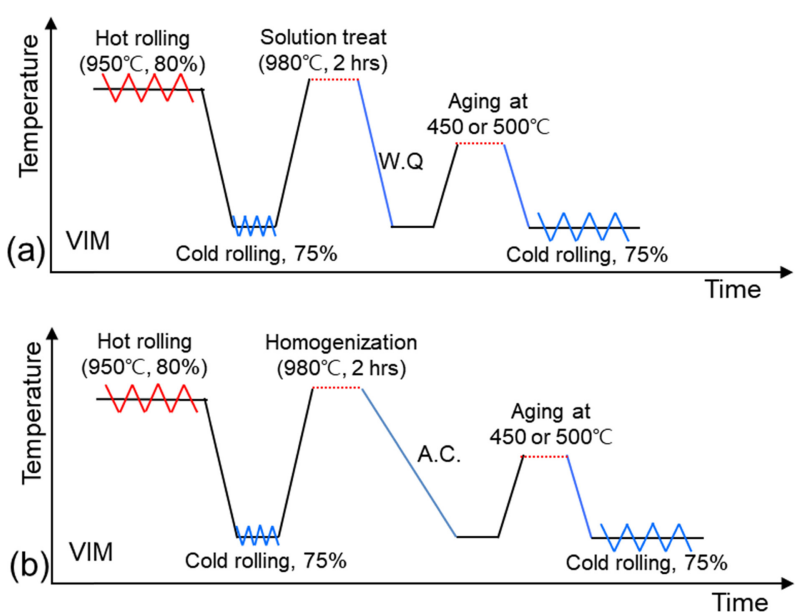

Fig. 1. Schematic diagrams of thermo-mechanical treatment processes for (a) solution and (b) homogenization treatment.

으로 시편의 전기저항을 4 번 측정하여 각 저항값을 \%IACS (International Annealed Copper Standard)로 환 산한 후에 평균값을 전기전도도로 산출하였다.

\section{3. 결 과}

그림 2 는 $980{ }^{\circ} \mathrm{C}$ 에서 균질화 처리 후 (그림 $\left.1, \mathrm{~b}\right) 450$ 및 $500{ }^{\circ} \mathrm{C}$ 에서 시효처리한 $\mathrm{Cu}-6 \mathrm{Ni}-1.4 \mathrm{Si}$ 합금의 전기전도 도 및 경도 변화를 나타내었다. 같은 조성의 합금을 용체 화 처리한 것[8]에 비해 균질화 초기 전기전도도와 경도가 높았다. 균질화 처리한 합금은 $500{ }^{\circ} \mathrm{C}$ 에서 60 분 시효할 경 우, 최고 경도를 보이다가 시효 시간이 증가될수록 감소하 는 경향을 나타내었다. 그런데, 그림 3에 나타낸 시효 시 간 증가에 따른 인장강도의 변화는 경도의 그 것과 다른 양상을 나타내었다. 두 시효온도의 조건에서 시효 후 인장 강도는 증가했음을 보였다 그런데, $500{ }^{\circ} \mathrm{C}$ 에서 시효한 경 우 급격한 경도 변화에서 보인 것과 달리, 인장강도의 큰 변화는 나타내지 않았다. 장시간 시효시 석출물 조대화가 경도에는 큰 영향을 미친 것으로 사료되지만 인장강도에는 그 다지 큰 영향을 미치지 않았다는 것을 의미한다. 국부 적인 미세구조에 영향을 받는 경도 보다는 시편의 종합적 인 구조를 표현하는 인장강도가 본 합금의 기계적 특성을 대표하는 특성이라고 할 수 있다.

현재까지의 결과를 종합하여, 최고의 전기전도도와 강도 조합을 나타내는 균질화 처리 후 $500{ }^{\circ} \mathrm{C}$ 에서 6 시간 시효 한 합금과 용체화 처리 후 동일 온도와 시간에서 시효한 합금을 $75 \%$ 단면적 감소율로 냉간 압연하여, 미세구조 변 화와 함께 기계적 특성 및 전기전도도의 변화를 분석하고
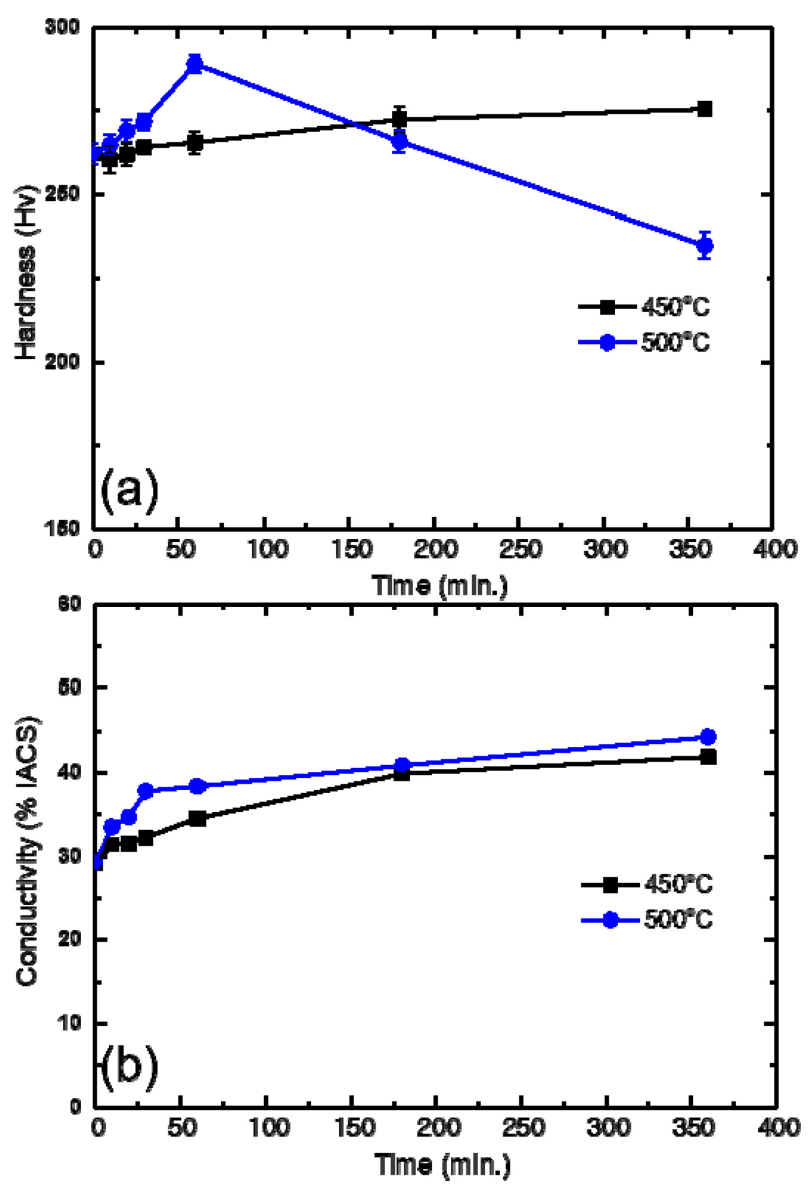

Fig. 2. (a) Hardness and (b) electrical conductivity change of homogenization treated $\mathrm{Cu}-6 \mathrm{Ni}-1.4 \mathrm{Si}$ alloy with increasing aging time

고찰하였다.

\section{4. 고 찰}

그림 4 는 $980{ }^{\circ} \mathrm{C}$ 에서 용체화 또는 균질화처리, 이어서 $500{ }^{\circ} \mathrm{C}$ 에서 6 시간 시효 그리고 마지막으로 $75 \%$ 단면적 감 소율로 냉간 압연한 $\mathrm{Cu}-6 \mathrm{Ni}-1.42 \mathrm{Si}$ 합금의 전기전도도와 경 도를 나타내었다. 용체화 처리된 시편이 균질화 처리된 시 편에 비해 낮은 전기전도도를 보였는데, 이는 잔류 고용된 원소에 의해 전기전도도가 감소하였을 것으로 생각된다. 그 런데 용체화 처리된 합금의 경도가 매우 높은 값을 보였다.

또한 그림 5 에 나타낸 바와 같이 인장강도 역시 용체화 처리 전 열간압연한 시편에 비해 높은 인장강도를 보였다. 이는 이전의 연구[8]에서 제조된 시편에 비해, 부피와 중량 (40 kg billet)이 크고, 용체화 처리 전 $75 \%$ 단면적 감소율 로 냉간 압연을 시행했기 때문으로 생각된다. 용체화 처리 

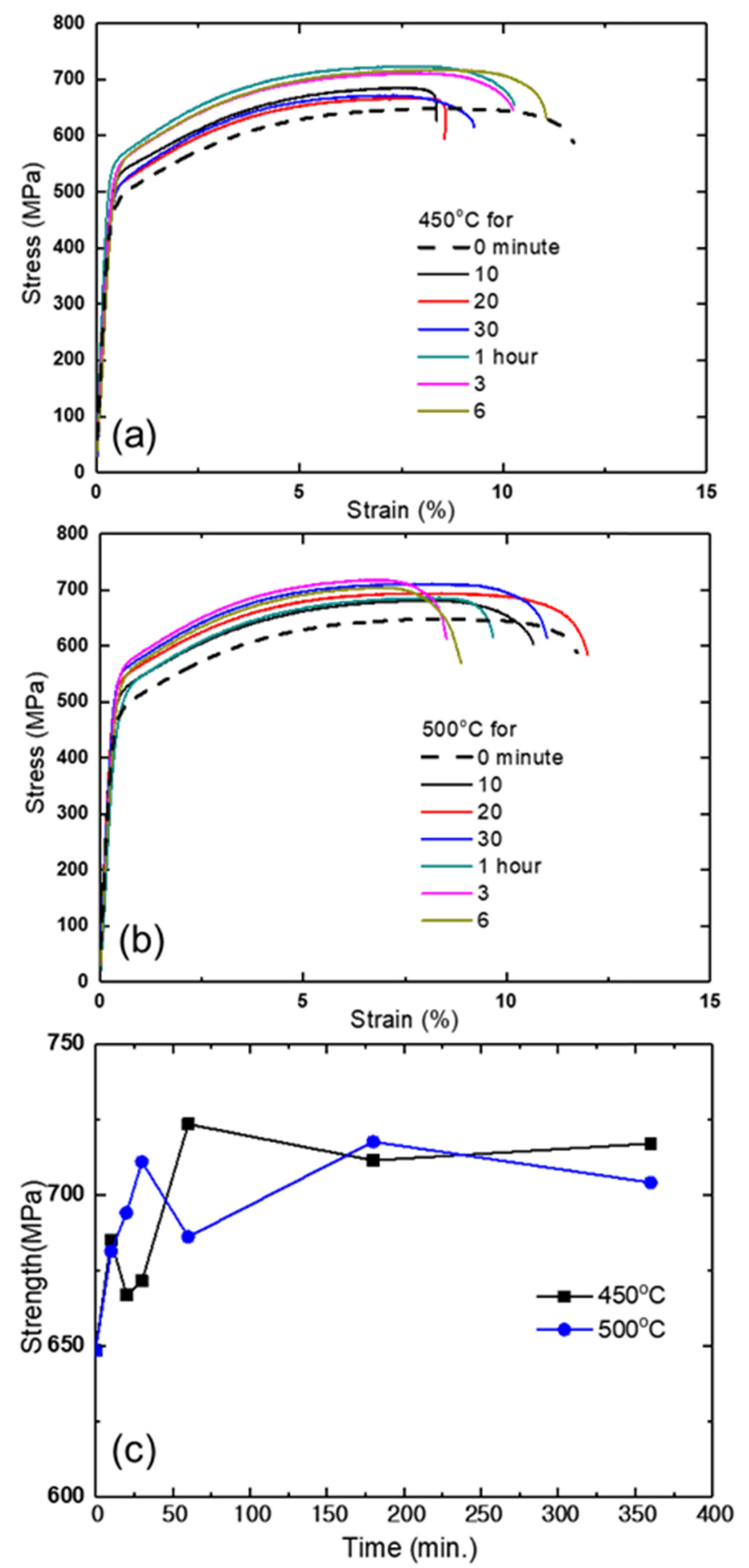

Fig. 3. Stress-strain curve of Cu-6Ni-1.42Si alloy aged at (a) $450{ }^{\circ} \mathrm{C}$ and (b) $500{ }^{\circ} \mathrm{C}$ after homogenization treatment and (c) strength change with increasing aging time after homogenization treatment. The dotted line describes the stress-strain curve of the alloy after homogenization treatment.

전 냉간가공은 합금의 결정립을 미세화 하고 합금원소의 효과적인 고용을 촉진하였을 것으로 사료된다.

그리고 본 합금은 구리 기지내 $\mathrm{Ni}$ 과 $\mathrm{Si}$ 의 최대고용도를 상회하는 조성을 가진다. 즉 높은 $\mathrm{Ni}$ 과 $\mathrm{Si}$ 함량은 고용이 효과적으로 이루어졌을 경우, 석출 구동력이 증가하여 석
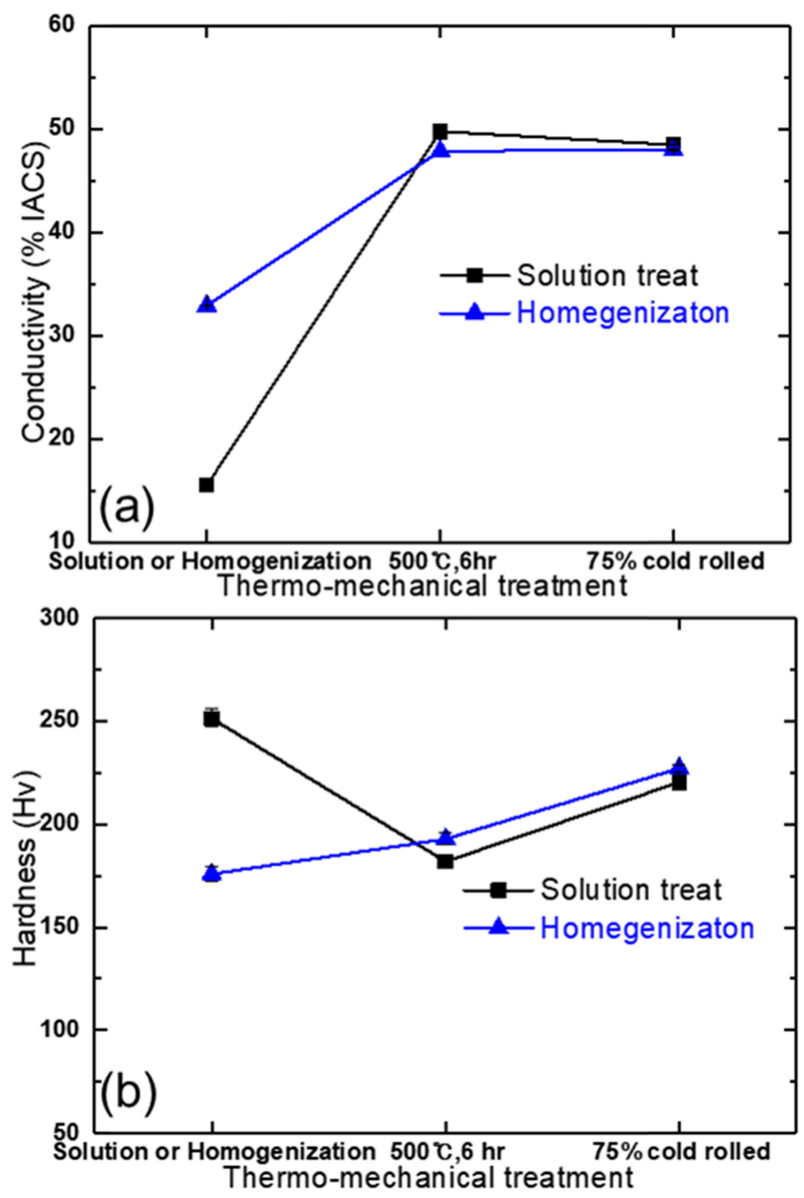

Fig. 4. (a) Electrical conductivity and (b) hardness change of $\mathrm{Cu}-$ $6 \mathrm{Ni}-1.4 \mathrm{Si}$ alloy with differential thermo-mechanical treat.

출을 가속화 시켰을 것으로 판단된다. 실제로 석출구동력 이 매우 큰 고용체는 담금질 정도의 냉각에도 매우 큰 석 출경화 효과를 나타내기도 한다 [24]. 또한 과포화 구간에 서 급냉시, 표면의 온도는 빠르게 감소하지만 큰 부피를 가진 합금 내부의 온도가 표면에 비해선 서서히 감소할 것 으로 판단된다. 석출이 일어나서, 고용 강화 이외에 석출 경화 효과로 강도를 증가시켰을 것을 생각된다.

용체화 및 균질화 처리 후 $500{ }^{\circ} \mathrm{C}$ 에서 6 시간 시효한 시편의 인장강도는 각각 $582 \mathrm{MPa}$ 및 $628 \mathrm{MPa}$ 을 나타내 었다. 그림 6에 용체화 처리 후, 그리고 시효한 시편과 균 질화 처리, 그리고 시효한 시편의 미세구조를 각각 나타내 었다.

용체화 및 균질화 처리 후, 시편의 결정립계면에 불균일 핵생성에 의해 생선된 입자가 관찰되었다. 균질화 처리된 시편에서 생성된 입계 석출물은 연속적인 벌크 형태를 가 지는 데 이는 앞서 언급한 것처럼 느린 냉각 속도에 의해 불균일 핵생성과 성장이 충분하게 이루어졌다는 것을 의미 

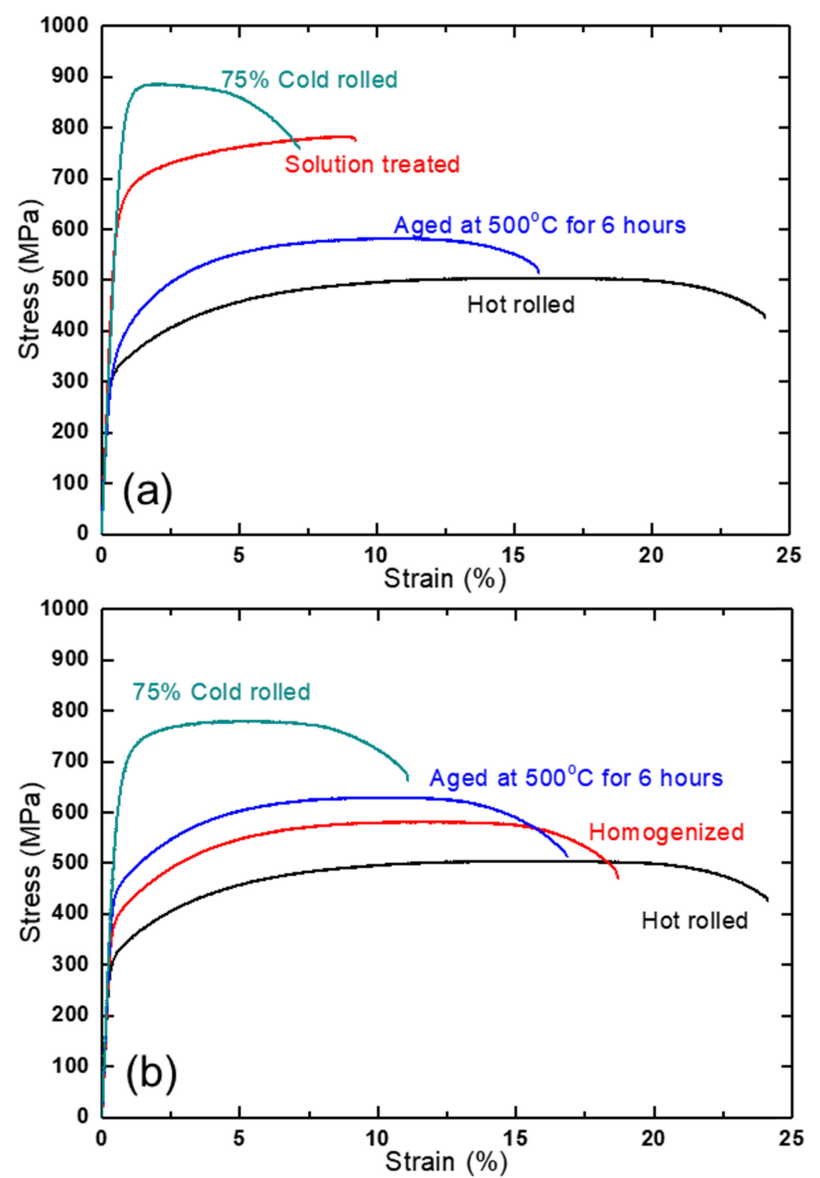

Fig. 5. Stress-strain curve of thermo-mechanically treated $\mathrm{Cu}-6 \mathrm{Ni}-$ $1.42 \mathrm{Si}$ alloy after (a) solution and (b) homogenization treatment.
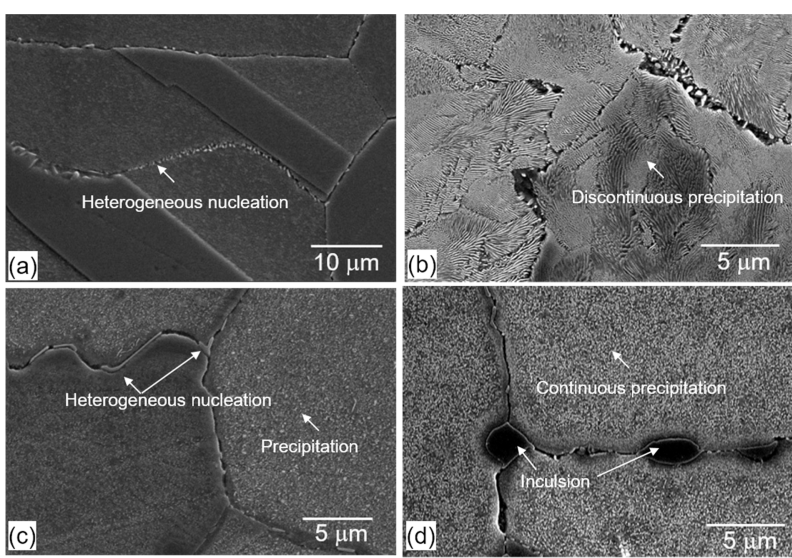

Fig. 6. Microstructure of $\mathrm{Cu}-6 \mathrm{Ni}-1.42 \mathrm{Si}$ alloy which was (a) solution treated and then (b) aged at $500{ }^{\circ} \mathrm{C}$ for 6 hours, and (c) homogenized and then aged at (d) $500{ }^{\circ} \mathrm{C}$ for 6 hours, respectively.

한다. 결정립내의 석출물은 냉각속도 차에 의해 매우 큰 차이를 보였는데, 용체화 처리시 $\mathrm{Ni}$ 과 $\mathrm{Si}$ 의 효과적인 고용 은 석출 구동력을 증가시켜서 불연속 석출을 조장한 [7]
반면 균질화 처리된 시편, 즉 서냉된 시편은 그림 6 (c)에 나타낸 것 과 같이 시효전임에도 불구하고 이미 석출이 일 어났다. 용체화 처리된 시편에 비해 서냉시 이미 석출된 $\mathrm{Ni}$ 과 $\mathrm{Si}$ 은 기지의 고용도가 낮아지고, 시효시 석출구동력 의 감소로 인해 불연속 석출이 억제되어 일반 석출 (normal or continuous precipitation) 이 일어난 것으로 사료된다.

높은 전기전도도를 확보하기 위한 장시간 즉, 6 시간 시 효에서 균질화 처리한 합금은 $48 \% \mathrm{IACS}$, 용체화 처리한 합금은 $50 \% \mathrm{IACS}$ 를 나타내었다. 이 것을 단면적 감소율 $75 \%$ 로 압연하였을 때, 그림 4 에 나타낸 바와 같이 전기전 도도는 균질화 처리한 합금은 $48 \% \mathrm{IACS}$ 를 유지하였고, 용체화 처리한 합금은 $48 \% \mathrm{IACS}$ 로 감소하였다. 전기전도 도 측정시 오차범위를 감안하더라도 두 합금 모두 시효 후 냉간가공시 전기전도도의 감소는 극히 미미한 것으로 나타 났다. 다른 원소가 고용된 구리가 순동에 비해 가공 경화 시킬 때 전기전도도의 감소폭이 큰 것을 고려한다면 $[25,26]$ 본 연구의 두 합금 모두 장시간의 시효로 인해, 구리 기지는 $\mathrm{Ni}$ 과 $\mathrm{Si}$ 의 평형고용도에 거의 도달한 것으로 예상된다. 즉 기지의 순도가 높아 가공경화에도 전기전도 도가 작게 감소되었다는 것을 의미한다.

그림 7은 용체화 및 균질화 처리 후 시효한 시편과 그 리고 그 것을 $75 \%$ 단면적 감소율로 냉간압연한 합금의 고화질 투과 전자현미경 분석결과를 나타내었다. 그림 7 (a)에 나타낸 바와 같이 시효 후 섬유형태의 $\mathrm{Ni}_{2} \mathrm{Si}$ 금속간 화합물이 불연속 석출로 생성되었고 이 것을 압연하였을 때, 그림 7 (b)와 같이 불연속 석출물 일부가 압연 중 배 향되었음을 보였다. 반면, 균질화 처리된 합금을 시효했을 때, 그림 7 (c)에 나타낸 바와 같이 디스크 형태의 $\mathrm{Ni}_{2} \mathrm{Si}$ 금속간화합물이 석출되었음이 확인되었다. 그리고 이 것을 압연했을 경우는 석출물의 크기나 형상이 그림 7 (d)에 나 타낸 것처럼 가공후 형태가 크기가 변화되지 않았음을 확 인하였다. 이는 그림 5 에 나타낸 바와 같이 용체화 또는 균질화 처리한 시편의 압연 후 강도 변화가 차이가 있음을 설명하는데 중요한 근거를 제공한다. 즉 균질화 처리한 시 편의 경우 압연 후 강도 증가는 가공경화에 의해 주로 일 어났음을 시사한다. Han 은[7], 섬유 형태의 석출물을 가 진 용체화 처리된 시편을 인발하였을 경우, 석출물의 배향 과 소성변형으로 인해 가공경화에 함께 부가적인 강도 상 승이 일어났다는 것을 보고 한 바 있는데, 본 연구의 압연 공정에서도 불연속 석출된 합금의 가공경화 이외에 부가적 인 강도 상승이 발생한다는 것을 확인하는 결과이다.

이상과 같이 용체화 및 균질화 처리 즉 단상고용영역을 


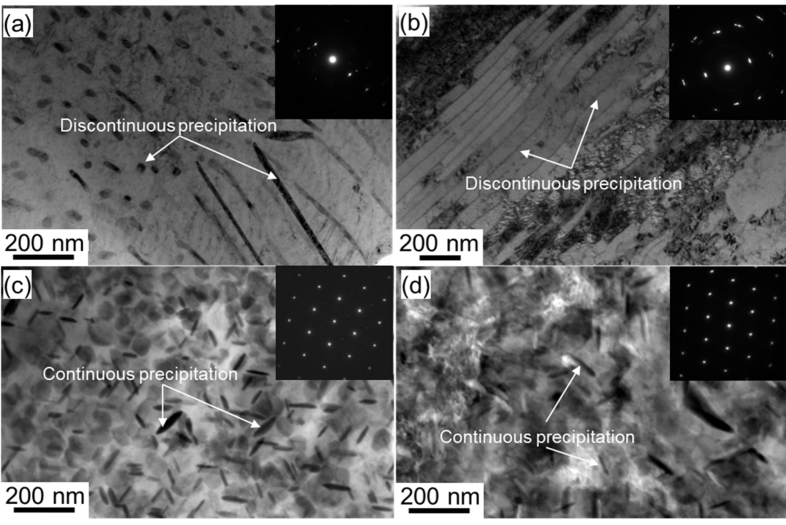

Fig. 7. Microstructure of $\mathrm{Cu}-6 \mathrm{Ni}-1.42 \mathrm{Si}$ alloy which was (a) aged at $500{ }^{\circ} \mathrm{C}$ for 6 hours and (b) successively cold rolled with $75 \%$ area reduction after solution treat, and (c) aged at $500{ }^{\circ} \mathrm{C}$ for 6 hours and (d) successively cold rolled with $75 \%$ area reduction after homogenization treat, respectively.

유지한 후 냉각속도 변화에 따라 $\mathrm{Ni}_{2} \mathrm{Si}$ 석출물의 형태를 극적으로 변화시킬 수 있었다. 불연속 석출을 억제하여 일 반 석출물을 생성시키기 위해 합금을 고용영역에서 서냉하 는 균질화 처리를 이용해야 한다. 용체화 및 균질화 처리 된 합금을 $500{ }^{\circ} \mathrm{C}$ 에서 6 시간 시효한 합금의 강도, 연신 율 그리고 전기전도도는 각각 $582 \mathrm{MPa}, 15.5 \%, 50$ $\% \mathrm{IACS}$, 그리고 $628 \mathrm{MPa}, 18 \%, 48 \% \mathrm{IACS}$ 를 나타내었 다. 그런데, 최종 냉간압연 후 용체화 및 균질화 처리된 합금의 강도, 연신율 그리고 전기전도도는 각각 $885 \mathrm{MPa}$, $6.5 \%, 48 \% \mathrm{IACS}$ 및 $774 \mathrm{MPa}, 10.5 \%, 48 \% \mathrm{IACS}$ 을 나타 내었다. 연성은 균질화 처리한 시편이 다소 우수한 것으로 나타났다. 이는 무작위로 분포된 섬유상 화합물이 국부적 인 소성변형을 야기해 비교적 균일하게 분산된 구형의 석 출물을 가진 합금에 비해 낮은 연성을 나타내는 것으로 해 석된다. 상온 소성 가공시, 섬유상 형태의 석출물은 배향과 소성변형을 일으켜 강도 증가에 더욱 효과적이라 할 수 있 다. 그런데, 용체화 처리, 즉 급냉이 요구되므로 매우 큰 규모의 합금에는 적용이 용이하지 않을 것으로 판단된다.

\section{5. 결 론}

본 연구는 $\mathrm{Cu}-6 \mathrm{wt} \% \mathrm{Ni}-1.42 \mathrm{wt} \% \mathrm{Si}$ 합금을 고온 단상 영역에서 유지한 후, 급냉 (용체화 처리) 및 서냉 (균질화 처리) 효과가 시효 및 냉간압연 후 기계적 특성 및 전기전 도도의 변화에 미치는 영향을 분석 및 고찰하였다.

용체화 및 균질화 처리된 합금을 $500{ }^{\circ} \mathrm{C}$ 에서 6 시간 시효한 합금의 강도, 연신율 그리고 전기전도도는 각각
$582 \mathrm{MPa}, 15.5 \%, 50 \% \mathrm{IACS}$, 그리고 $628 \mathrm{MPa}, 18 \%, 48$ $\% \mathrm{IACS}$ 를 나타내었다.

$500{ }^{\circ} \mathrm{C}$ 에서 6 시간 시효후 $95 \%$ 냉간압연시, 용체화 및 균질화 처리된 합금의 강도, 연신율 그리고 전기전도도는 각각 $885 \mathrm{MPa}, 6.5 \%, 48 \% \mathrm{IACS}$ 및 $774 \mathrm{MPa}, 10.5 \%$, $48 \% \mathrm{IACS}$ 을 나타내었다.

용체화 처리후 시효시, 불연속 석출로 인해 섬유상 형태 의 $\mathrm{Ni}_{2} \mathrm{Si}$ 화합물이 생성되었다. 반면, 균질화 처리후 시효 시, 디스크 형태의 $\mathrm{Ni}_{2} \mathrm{Si}$ 화합물이 생성되었다.

\section{ACKNOWLEDGMENTS}

This work was supported principally by Global Frontier R\&D Program (2013M3A6B1078874) on Global Frontier Hybrid Interface Materials R\&D Center funded by the Ministry of Science, ICT, and Future Planning and the National Research Foundation of Korea (NRF) grant funded by the Korea government (MSIP) [No. 2018R1A5A6075959].

\section{REFERENCES}

1. Y. B. Jeong, S. H. Hong, J. T. Kim, H. J. Park, Y. S. Kim, H. D. Lee, J. K. Lee, S. C. Mun, Y. J. Hwang, K. Heo, and K. B. Kim, Met. Mater. Int. 25, 539 (2019).

2. Y. B. Jeong, J. T. Kim, S. H. Hong, H. D. Lee, S. Y. Choi, and K. B. Kim, Mater. Des. 175, 107814 (2019).

3. S. Z. Han, J. Lee, M. Goto, S. H. Lim, J. H. Ahn, S. Kim, and K. Kim, Phil. Mag. Lett. 96, 196 (2016).

4. S. Z. Han, H. Joh, J. H. Ahn, J. Lee, S. M Kim, S. H. Lim, and Y. G. Son, J. Alloy. Compd. 622, 384 (2015).

5. S. Z. Han, K. H. Kim, J. Kang, H. Joh, S. M. Kim, J. H. Ahn, J. Lee, S. H. Lim, and B. Han, Sci. Rep. 5, 17364 (2015).

6. S. Z. Han, J. H. Ahn, Y. S. You, J. H. Lee, M. Goto, K. H. Kim, S. S. Kim, Korea J. Met. Mater. 24, 23 (2018).

7. S. Z. Han, S. H. Lim, S. Kim, J. Lee, M. Goto, H. G. Kim, B. Han, and K. Kim, Sci. Rep. 6, 30907 (2016).

8. S. Z. Han, J. Lee, S. H. Lim, J. H. Ahn, K. Kim, and S. Kim, Met. Mater. Int. 22, 1049 (2016).

9. S. Suzuki, N. Shibutani, K. Miura, M. Isshiki, and Y. Waseda, J. Alloy. Compd. 417, 116 (2006).

10. Q. Lei, Z. Li, T. Xiao, Y. Pang, Z. Q. Xiang, W. T. Qiu, and Z. Xiao, Intermetallics 42, 77 (2013).

11. J. H. Ahn, D. W. Kim, M. S. Kim, J. H. Hwang, and S. Z. Han, Korean J. Met. Mater. 55, 537 (2017). 
12. Y. Kim, J. Kwon, D. Yoo, S. Park, D. Lee, and D. Lee, Korean J. Met. Mater. 55, 165 (2017).

13. M. A. Jo, E. A. Choi, J. H. Ahn, Y. G. Son, K. H. Kim, J. H. Lee, S. Sembosi, S. Z. Han, Korea J. Met. Mater. 57, 10 (2019).

14. S. nagarjuna and K. balasubramanian, J. Mater. Sci. 34, 2929 (1999).

15. W. A. Soffa and D. E. Laughlin, Prog. Mater. Sci. 49, 347 (2004).

16. S. Nagarjuna, M. Srinivas, K. Balasubramanian, and D. S. Sarma, Mat. Sci. Eng. A 259, 34 (1999).

17. S. Semboshi, E. Hinamoto, and A. Iwase, Mater. Lett. 131, 90 (2014).

18. J. D. Verhoeven, S. C. Chueh, and E. D. Gibson, J. Meter. Sci. 24, 1748 (1989).

19. D. P. Lu, J. Wang, W. J. Zeng, Y. Lio, L. Lu, and B. D. Sun,
Mat. Sci. Eng. A 421, 254 (2006).

20. ASTM, Standard Test Method for Resistivity of Electrical Conductor Materials, ASTM B193-19, p. 1, ASTM international, USA (2019).

21. L. Yagmur, Mat. Sci. Eng. A 523, 65 (2009).

22. P. Behjati, H. V. Dastjerdi, and R. Mahdavi, J. Alloy. Compd. 505, 739 (2010).

23. S. Semboshi, Y. Kaneno, T. Takasugi, S. Z. Han, and N. Masahashi, Metall. Mater. Trans. A 50, 1389 (2019).

24. S. Z. Han, E. A. Choi, H. W. Park, S. H. Lim, J. Lee, J. H. Ahn, N. M. Hwang, and K. Kim, Sci. Rep. 7, 12195 (2017).

25. S. Nestorovic, D. Markioovic, and L. Ivanic, Bull. Mater. Sci. 26, 601 (2003).

26. J. H. Ahn, S. Z. Han, B. W. Ahn, S. B. Jung, S. H. Lim, and S. Kim, J. Jpn. Inst. Copp. 53, 16 (2014). 